\title{
STRUCTURAL COMPLEXITY OF SUBSTRATA AND ANTIFOULING PAINT EFFECTS ON SPATIAL DISTRIBUTION OF Conodon nobilis LINNAEUS, 1758 (TELEOSTEI, ACTINOPTERYGII)*
}

\author{
Daniel Shimada Brotto ${ }^{1}$ and Ilana Rosental Zalmon ${ }^{2}$ \\ ${ }^{1}$ Universidade Veiga de Almeida - CCBS \\ (Rua Ibituruna, 108, 20271-020 Rio de Janeiro, RJ, Brasil) \\ danshima@ig.com.br \\ ${ }^{2}$ Universidade Estadual do Norte Fluminense - LCA \\ (Av. Alberto Lamego 2000, 28013-602 Campos, RJ, Brasil) \\ ilana@uenf.br
}

Artisanal fishery plays a secondary role in the economy of northern Rio de Janeiro state. The lack of rocky shores and safe moorings might be the main factors preventing higher fisheries activity in the region. Artificial reefs have been used worldwide as a strategy to increment fisheries justifying related researches in the area. The deployment of an artificial reef at Rio de Janeiro north coast in 1996 revealed a high abundance of several fish species (GOMES et al., 2001; FARIA et al., 2001; GODOY et al., 2002; ZALMON et al., 2002; GOMES et al., 2004; BROTTO et al., 2006a; 2006b), such as Conodon nobilis, a marine demersal fish usually found along sandy shores and over shallow muddy bottoms (www.fishbase.org), which might be using the reef units for shelter. The objective of this study is to test the structural substrata complexity effects and the A

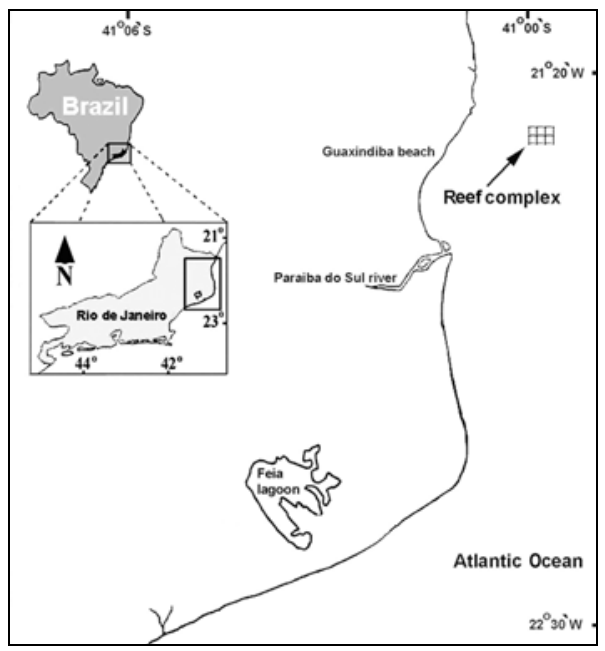

fouling community presence in Conodon nobilis spatial distribution when a large school was present on our artificial reefs.

In January 2002 a reef complex was placed in water $9 \mathrm{~m}$ deep, 3.0 miles north of Guaxindiba Beach $\left(21^{\circ} 29^{\prime} \mathrm{S}, 41^{\circ} 00^{\prime} \mathrm{W}\right)$ on a flat and homogeneous sand bottom (Fig. 1A). A total of 36 prefabricated concrete reef balls $1 \mathrm{~m}$ high and $1 \mathrm{~m}$ wide were distributed in 12 experimental units of four types according to the combination of structural complexity through the presence (with cavities - WC) or absence (no cavities - NC) of $20 \mathrm{~cm}$ holes/cavities and favorable (with antifouling - WA) or unfavorable (No antifouling - NA) surface for epibenthic colonization with antifouling paint (Tritão Cooperkote - Akzo Nobel Coatings) (Fig. 1B).

\section{B}

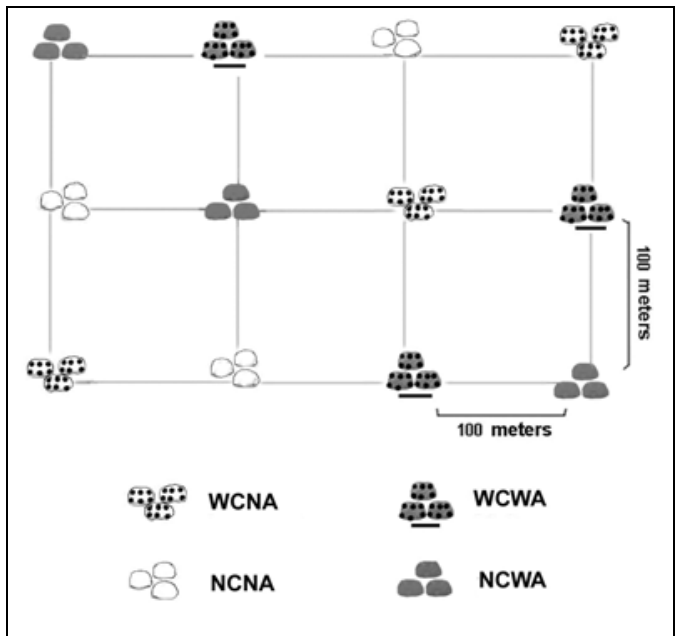

Fig.1. A. Location of the experimental artificial reef (AR) on the north coast of the state of Rio de Janeiro. B. Spatial distribution of the experimental units (WCNA - with cavities/no antifouling; WCWA - with cavities/with antifouling; NCNA non cavities /no antifouling; NCWA - non cavities/with antifouling; $\mathrm{N}=3$ in each module type).

(*) Paper presented at the $1^{\text {st }}$ Brazilian Congress of Marine Biology, on 15-19 May. Rio de Janeiro, Brazil, 2006. 
The fish sampling program consisted of 12 bottom gill nets (15 long x $4 \mathrm{~m}$ high, $30 \mathrm{~mm}$ mesh), each one being placed across the 12 experimental units for a 24 $\mathrm{h}$ period. The fishes were grouped according to the experimental designation of each module type. A total of 248 specimens of $C$. nobilis were caught in April 2003 and selected to the analysis. Each one was measured, weighted and classified by sex. Fish abundance, standard lengths and individual weight values of each net (three on each treatment) among module types were tested by ANOVA followed by $a$ posteriori Tukey test. Sex ratio by module type was analyzed using a Chi-square test $\left(X^{2}\right)$. The frequency distribution of length and weight was compared among module types and the relation between standard lengths $v s$. weight on the different module types was analyzed by Spearman Correlation index.

At non-complex/with antifouling (NCWA) modules 76 individuals were caught followed by non-complex/no antifouling modules (NCNA) with 70 individuals; 54 at complex/with antifouling (WCWA) and 48 at complex/no antifouling modules (WCNA). The mean individual number of the three nets by module type varied from 16 (WCNA) to 25 fish (NCWA) with higher variability among nets of the same experimental unit at modules with antifouling (Fig. 2). No significant differences ( $\mathrm{F}=$ $4.40, p=0.103$ and $\mathrm{F}=1.67, p=0.252$ ) were found between fish abundance among module types.
Male fish were more abundant than female at the four module types (Fig. 3). Females seemed to be more abundant than fish of unidentified sex, although no significant differences were present $\left(\mathrm{X}^{2}\right.$ $=4.82$ and $p=0.70$ ) among the proportions.

Fish with higher standard lengths were more abundant at non-complex modules than at complex ones $(15.69 \pm 2.37 \mathrm{~cm}$ at NCNA, $15.31 \pm$ $2.27 \mathrm{~cm}$ at NCWA, $15.15 \pm 2.15 \mathrm{~cm}$ at WCNA, 14.94 $\pm 2.47 \mathrm{~cm}$ at WCWA). At non-complex/no antifouling (NCNA) fish standard lengths were significantly $(\mathrm{F}=3.15$ and $p=0.026)$ different from the values from the fish around the complex/with antifouling (WCWA) (Fig. 4). A similar pattern was observed for $C$. nobilis weight, although no significant differences $(\mathrm{F}=1.18$ and $p=0.319)$ were found among fish from the four module types. A high weight variability between the units was observed in each module type (Fig. 4). The correlation between standard length and weight were both positive and strong $(r<0.05)$ in the four module types. The highest regression coefficients at the complex reef units (WCNA and WCWA), 0.83 and 0.90 respectively provide an acceptable equation relating length and weight (Fig. 5) and reflect a stronger association of these parameters at more complex substrates.

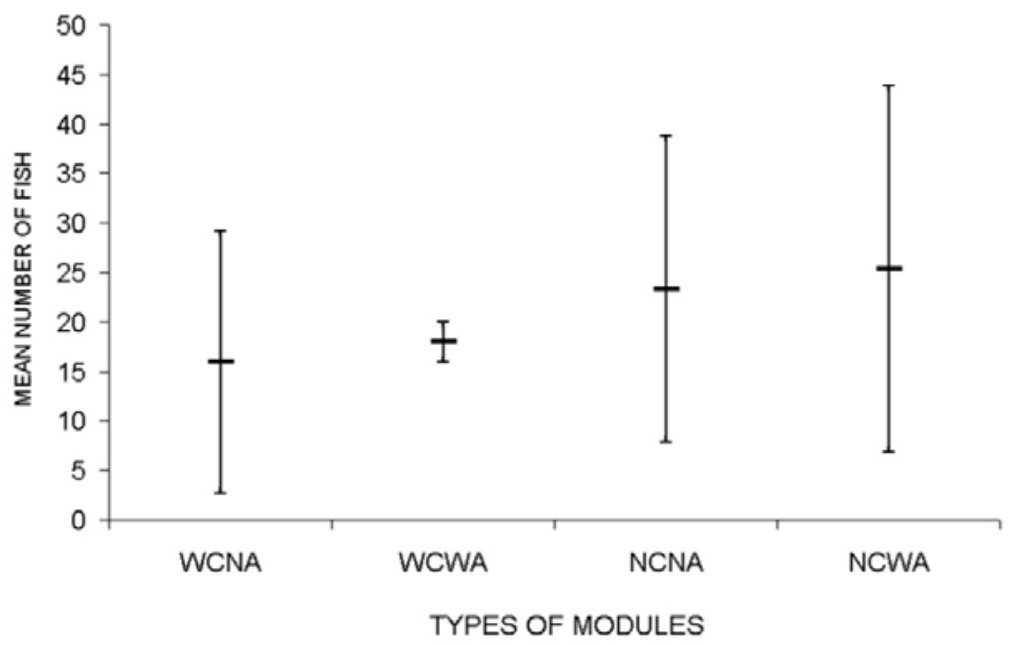

Fig. 2. Mean fish number \pm standard deviation of $C$. nobilis at different module types (WCNA - with cavities/no antifouling; WCWA - with cavities/with antifouling; NCNA non cavities /no antifouling; NCWA - non cavities/with antifouling; $\mathrm{N}=3$ in each module type). 


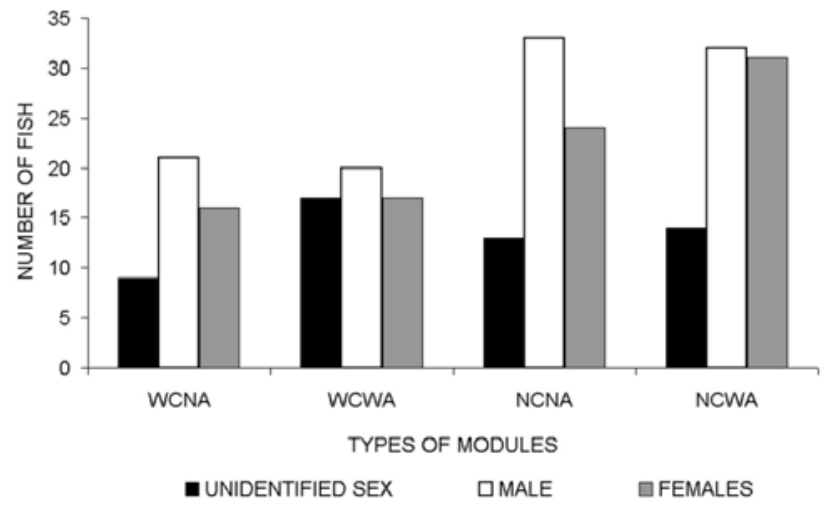

Fig. 3. Number of male, female and unidentified sex fish of $C$. nobilis by module type (WCNA - with cavities/no antifouling; WCWA - with cavities/with antifouling; NCNA - non cavities/ no antifouling; NCWA - non cavities/ with antifouling).
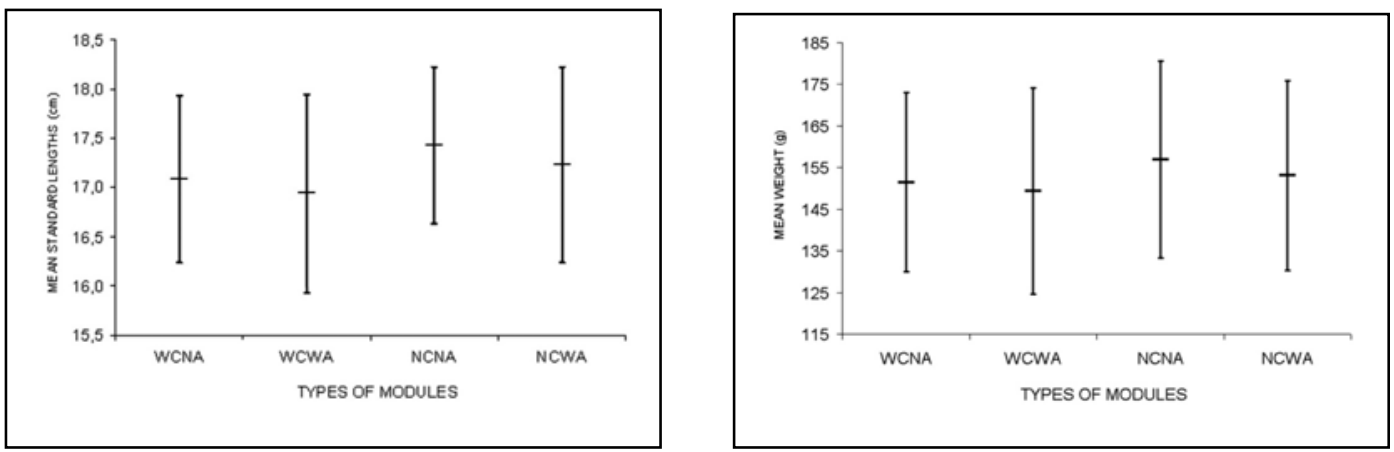

Fig. 4. Mean standard length $(\mathrm{cm})$ and weight $(\mathrm{g})$ of fish \pm standard deviation of $C$. nobilis at different module types (WCNA - with cavities/no antifouling; WCWA - with cavities/with antifouling; NCNA - non cavities/no antifouling; NCWA - non cavities/with antifouling).
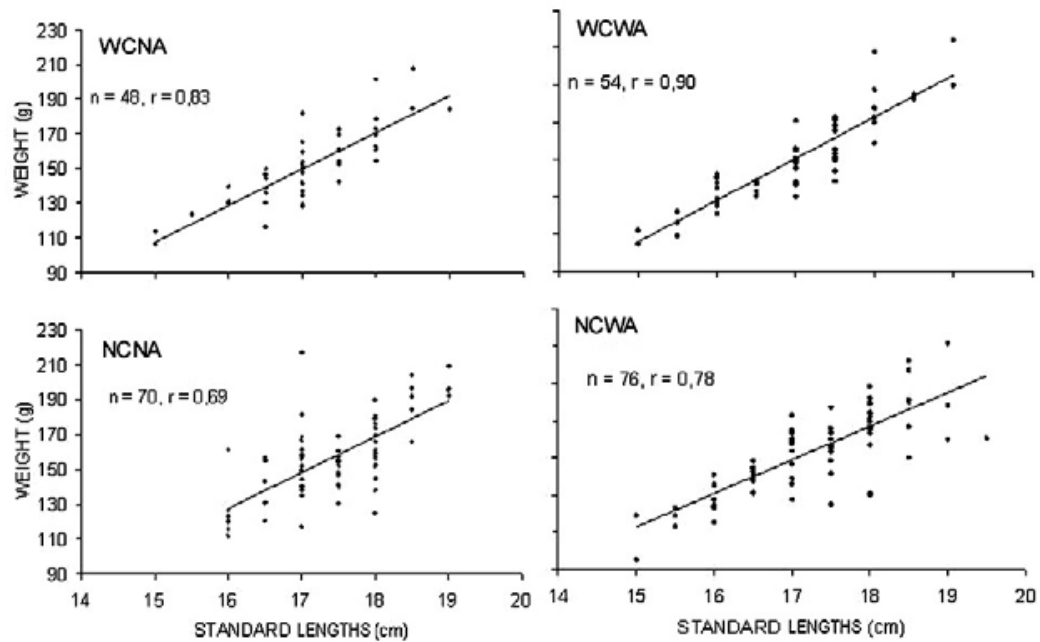

Fig. 5. Frequency distribution of $C$. nobilis by standard length (A) and by weight (B) at different module types (WCNA - with cavities/no antifouling; WCWA - with cavities/with antifouling; NCNA - non cavities/no antifouling; NCWA - non cavities/with antifouling). 
Frequency distribution by standard length and weight revealed a Poisson distribution (variation coefficient $<20$ ) at the four module types. Higher length variability at non-complex modules (NCNA and NCWA) reflects the presence of two modal classes (17,5-18,0 cm and 16,5-17,0 cm) (Fig. 6), which might reflect a low dependence for shelter by larger specimens as observed by Beets and Hixon (1994).

The fouling community recruitment and succession was monthly investigated during two years and showed the antifouling paint effectiveness for eight months with the initial settlement of hydroids, barnacles and oysters followed by sponges and carijoa (KROHLING et al., 2006). Therefore, after September 2002 the fouling community on all the experimental modules was very similar and should have no differential effect upon C. nobilis assemblage.

Substrate complexity plays an important role in reef fish community structure (BROTTO and ARAUJO, 2000; D'ANNA et al., 2004) although some artificial reef environments show a seasonal influence as a factor of major importance. Godoy et al. (2002) registered significant seasonal variations in the fish assemblage at this same artificial reef, and concluded that seasonality of hydrological parameters such as the Paraiba do Sul River outflow and pluviosity were the most important when modeling the local fish community. As hydrological parameters have direct influence on fish physiology and behavior the hypothesis of seasonal variation of hydrological parameters as a modeling agent to fish assemblages at artificial reefs should be considered, as stated by Bortone et al. (1994) and Fabi and Fiorentini (1994).

Godefroid et al. (2004) observed a seasonal dissimilarity in the fish community along the Parana coast, which was related to a high variability in the density of Conodon nobilis, Selene setapinnis and Stelifer rastrifer density. The authors suggest that this could reflect a straight forward adaptability of these species to environmental conditions as well as a temporal pattern of resource partitioning. Therefore, the occurrence of a large number of this fish species at the reef complex in a fall month could be related to seasonal movements rather than to the effective use of the reef modules as habitats, which in this case might represent a temporary shelter.

The low dependence on rock substrate, which is common to C. nobilis (COURTENAY et al., 1978), reflected in a non-significant difference among module types for mostly all the analyzed parameters and also in a similar behavior pattern at the four treatments; the fish was evenly distributed among the reef units without preference. Juveniles and adults of C. nobilis form schools that feed at night on small fish and invertebrates over sand and muddy sea beds (COURTENAY et al., op cit.) and eventually algal beds (VASCONCELOS-FILHO et al., 1984). Thus, it is a species not strongly associated with reef environment. The $100 \mathrm{~m}$ distance between adjacent reefs might be not large enough and $C$. nobilis assemblages should be gathering on different reefballs at day time and dispersing themselves around the reefs at dusk. On the next morning they move back to the nearest reefs without module type preference searching for shelter. Fowler et al. (1999) studying the diel activity of Trisopterus luscus on the Poole Bay artificial reef revealed that this small gadoid sheltered on the reef during the day and foraged off reef at night.
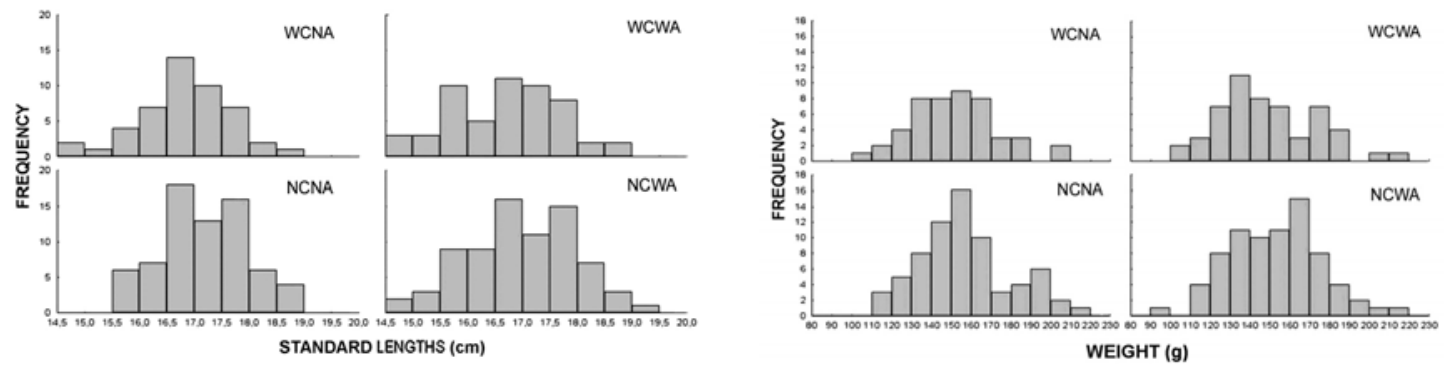

Fig. 6. Frequency distribution of C. nobilis by standard length (A) and by weight (B) at different module types (WCNA - with cavities/no antifouling; WCWA - with cavities/with antifouling; NCNA - non cavities/no antifouling; NCWA - non cavities/with antifouling). 
The different experimental conditions did not show to be relevant to $C$. nobilis assemblages. The height and shape of the whole artificial structure were similar at all module types, and no other factor should be influencing the fish diurnal habitat selection, but shelter. However, these results should be related to the adjacent reefs distance, the height and shape modules, and to $C$. nobilis behavior to both factors, which seems to form inactive, non-feeding schools around artificial reef units.

\section{ACKNOWLEDGEMENTS}

We would like to thank CNPq (Brazil`s Scientific and Technological Development Council) and FAPERJ (Rio de Janeiro Research Foundation) for the financial support for this research; and two anonymous referees for constructive comments on the draft manuscript.

\section{REFERENCES}

BEETS, J.; HIXON, M. A. Distribution, persistence, and growth of groupers (Pisces: Serranidae) on artificial and natural patch reefs in the Virgin islands Bull. mar. Sci., v. 55, n.2-3, p. $470-483,1994$.

BORTONE, S. A.; MARTIN, T.; BUNDRICK, C. M. Factors affecting fish assemblage development on a modular artificial reef in northern Gulf of Mexico estuary. Bull. mar. Sci., v. 55, p. 319-332, 1994.

BROTTO, D. S.; ARAÚJO, F. G. Habitat selection by fish in an artificial reef in Illha Grande bay, Brazil. Braz. Arch. Biol. Techn., v. 44, n. 3, p. 319-324, 2000.

BROTTO, D. S; KROHLING, W.; ZALMON, I. R. Usage patterns of an artificial reef by the fish community on the northern coast of Rio de Janeiro. J. coast. Res., v. 39, p. 1277-1281. 2006a.

BROTTO, D. S.; KROHLING, W.; ZALMON, I. R. Fish community modeling agents on an artificial reef on the northern coast of Rio de Janeiro - Brazil. Braz. J. Oceanogr., v. 54, n. 4, p. 205-212., 2006 b.

COURTENAY, W. R.; SAHLMAN, H. F. POMADASYIDAE. In: FISCHER, W., ed. FAO species identification sheets for fishery purposes: Western Central Atlantic (Fishing Area 31), FAO, Rome, n. 4, p. 197-231, 1978
D'ANNA, G.; GIACALONE, V. M.; BADALAMENTI, F.; PIPITONE, C. Releasing of hatchery-reared juveniles of the white seabream Diplodus sargus (L. 1758) in the Gulf of Castellammare artificial reef area (NW Sicily). Aquaculture, v. 233, p. 251-268, 2004.

FABI, G.; FIORENTINI, L. Comparison between an artificial reef and a control site in the Adriatic Sea: analysis of four years of monitoring. Bull. mar. Sci., v. 55, p. 538-558, 2004.

FARIA, V. V.; NOVELLI, R.; GOMES, M. P.; ZALMON, I. R. Potencial atrator de peixes cartilaginosos em recife artificial no litoral Norte do estado do Rio de Janeiro. Rev. brasil. Zool., v. 18, n. 3, p. 813-821, 2001.

FOWLER, A. J.; JENSEN, A. C.; COLLINS, K. J.; SMITH, I. P. Age structure and diel activity of pouting on the Poole Bay artificial reef. J. Fish. Biol., v. 54, n. 5, p. 944-954, 1999

GODEFROID, R. S.; SPACH, H. L. ; SANTOS, C. Temporal changes in the abundance and diversity of the fish fauna in the shallow infralittoral of a beach, southern Brazil. Iheringia, sér. Zool., v. 94, n. 1, p. 95-104, 2004.

GODOY, E. A. S.; ALMEIDA, T. C. M. ; ZALMON, I. R. Fish assemblages and environmental variables on an artificial reef - Rio de Janeiro, Brazil. ICES J. mar. Sci. , v. 59, p. S138-S143, 2002.

GOMES, M. P.; NOVELLI, R., ZALMON, I. R. Attraction of Chloroscombrus crysurus (Linnaeus, 1776) (Teleostei: Carangidae) by artificial reefs on the Northern Coast of Rio de Janeiro. Acta biol. Leolpoldensia, v. 26, n. 2, p. :19, 2004.

KROHLING, W.; BROTTO, D. S.; ZALMON, I. R. Functional role of fouling community on an artificial reef at the northern coast of Rio de Janeiro state, Brazil. Braz. J. Oceanogr., v. 54, n. 4, p. 183-191, 2006

VASCONCELOS-FILHO, A. L.; GUEDES, D. S.; GALIZA, E. M. B.; AZEVEDO-ARAUJO, S. Ecologic study of the Itamaraca zone, Pernambuco-Brazil. 27. Feeding habits of some estuarine fishes. Trab. Oceanogr. Univ. Fed. Pernambuco, v. 18, p. 231-260, 1984.

ZALMON, I. R.; NOVELLI, R.; GOMES, M. P.; FARIA, V. Experimental results of an artificial reef program on the Brazilian coast north of Rio de Janeiro. ICES J. mar. Sci., v. 59 , p. S83-S87. 2002

(Manuscript received 09 June 2006; revised 13 August 2007; accepted 12 November 2007) 